\title{
ENAM DEKAD GRAND STRATEGY MALAYSIA TERHADAP CHINA (1957-2018): DASAR LUAR NEGARA MEMBANGUN TERHADAP NEGARA KUAT
}

\author{
Mohammad Ikhram Mohammad Ridzuan, \\ Mohd Ikbal Mohd Huda \& Sity Daud
}

\begin{abstract}
This article analyzes the change in Malaysia's foreign policy towards China over the course of six decades from 1957 to 2018. It looks at the evolution of Malaysia's foreign policy towards China through three structured levels of analysis; the international, domestic and individual structure. Although there is no crisis that threatens the stability of both countries in the Kuala LumpurBeijing relations, there is still the perception of threat from external factors and pressures. Three factors dominating Malaysia's foreign policy towards China are analyzed in order to obtain coherency in the research results. First, the paper looks at the international factor concerning large power relations such as the United States and China relations which directly impacts Malaysia's foreign policy. Second is the domestic factor, which is the local economic change and political crisis. Finally, it looks at the individual factor through the leader's ideology and perception that plays a role in determining the direction of Malaysia's foreign policy. Neoclassical realism and the grand strategy concept are applied to study the connection between these three factors in the structuring of Malaysia's foreign policy towards China. These three international, domestic and individual factors have had significant impacts in influencing Malaysia's foreign policy towards China since the Cold War to 2018. However, it is the international structure that has played the most significant factor in domestic changes and the actions taken by leaders in the foreign policy shift that Malaysia has taken towards China.
\end{abstract}

Keywords: Malaysia, China, Foreign Policy, International Structure, Domestic,

\begin{abstract}
ABSTRAK
Artikel ini menganalisis perubahan dasar luar Malaysia terhadap China bagi tempoh enam dekad daripada tahun 1957 hingga 2018. Evolusi perubahan dasar luar Malaysia terhadap China distrukturkan melalui tiga peringkat analisis iaitu faktor struktur antarabangsa, domestik dan individu. Walaupun hubungan Kuala Lumpur-Beijing tidak memperlihatkan sebarang bentuk krisis yang mampu mengganggu gugat kestabilan kedua-dua negara, persepsi ancaman dilihat masih wujud berdasarkan faktor dan pengaruh luaran. Dalam mendapatkan hasil kajian yang koheren, tiga faktor yang mendominasi dasar luar Malaysia terhadap China dianalisis. Faktor struktur antarabangsa ialah hubungan antara kuasa-kuasa besar seperti Amerika Syarikat dan China yang memberikan kesan secara langsung terhadap dasar luar Malaysia. Faktor domestik pula ialah
\end{abstract}


perubahan ekonomi negara dan krisis politik. Faktor individu ialah peranan pemimpin dalam menentukan hala tuju dasar luar Malaysia melalui ideologi dan persepsi. Teori neoklasikal realisme dan konsep grand strategy diaplikasikan untuk mengkaji perkaitan hubungan tiga peringkat analisis tersebut dalam penstrukturan dasar luar Malaysia terhadap China. Ketiga-tiga faktor iaitu struktur antarabangsa, domestik dan individu memberikan impak yang tinggi dalam mempengaruhi perubahan dasar luar Malaysia terhadap China iaitu daripada era Perang Dingin sehingga tahun 2018. Walaupun demikian, faktor struktur antarabangsa paling signifikan kerana memberikan implikasi yang besar kepada perubahan domestik dan tindakan yang diambil oleh para pemimpin dalam menganalisis setiap perubahan dasar luar Malaysia terhadap China

Kata kunci: Malaysia, China, Dasar Luar, Struktur Antarabangsa, Domestik

\section{Pengenalan}

Kejatuhan Kesatuan Soviet menjadi parameter kepada evolusi sistem politik antarabangsa baru. Kematian Mao Zedong pada tahun 1976 dan era modenisasi ekonomi China pada tahun 1978 juga memberikan implikasi yang signifikan kepada Malaysia. Antara kesan tersebut ialah penstrukturan dasar luar Malaysia terhadap China daripada saling bermusuhan sehingga China menjadi rakan diplomasi. Tambahan pula perubahan secara dramatik dalam landskap politik dunia seperti kemenangan Donald Trump, pengenalan Laluan Sutera Baharu China, Perang Perdagangan Amerika Syarikat dengan China dan isu di Laut China Selatan juga memberi kesan kepada hubungan Malaysia-China. Kesemua peristiwa tersebut menuntut para pemimpin elit Malaysia untuk mengadaptasikan polisi playing the field dengan perubahan struktur antarabangsa. Playing the field bermaksud memaksimumkan strategi iaitu pakatan, pengimbangan mahupun perlindungan dalam dasar luar untuk memastikan kelangsungan dalam kalangan komuniti antarabangsa.

Ramai pengkaji berhujah bahawa pembentukan dan penggubalan dasar luar negaranegara dunia ketiga didominasi oleh faktor pemimpin.1 Pemimpin elit berpengaruh untuk memberikan kata putus dalam melaksanakan sesuatu keputusan.2 Analisis mendapati bahawa personaliti pemimpin mempunyai ikatan yang kuat dengan negara-negara kecil. Sebagai contoh Corbeet \& Veenendafi menyatakan bahawa politics in small states tend to be highly reliant on informal dynamics and then personal characteristic of key leaders and elite. 3 Walaupun demikian Ayoob berhujah bahawa faktor struktur antarabangsa dan domestik turut mempengaruhi penstrukturan dasar luar sesebuah negara kerana memberikan implikasi dalam bentuk peluang atau ancaman kepada sesebuah negara4 Tambahan pula, pembentukan dasar luar sesebuah negara bukan sahaja dipengaruhi faktor individu tetapi juga oleh struktur antarabangsa dan domestik.

\section{Enam Dekad Grand Strategy Malaysia terhadap China (1957-2018)}

\footnotetext{
1 Bahgaf, K. 1984. Foreign Policy in the Third World: An Introduction, International Political Sciences Review. 5(1), hlmn. 7-20; Huntington, S, “Democracy Third Wave," Journal of Democracy, 2(2), 1991, hlmn. 12-34. 2 Huntington, S, “Democracy Third Wave," Journal of Democracy, 2(2), 1991, hlmn. 12-34; Bahgaf, K. 1984. Foreign policy in the Third World: An introduction. International Political Sciences Review. 5(1), hlm. 7-20 ${ }_{3}$ Corbett, J. dan Veenendaal, W, Democracy in small states: Persistingagainst all odds, Oxford University Press. London, 2018.

4 Ayoob, A. The Third World Security Predicament: State making, Regional Conflict, and the International System, Lynne Rienner Publishers, United States, 1995.
} 
Hubungan vis-à-vis Malaysia dengan China terdiri daripada empat tempoh masa iaitu yang pertama ialah Persidangan Afro-Asian pada tahun 1955 yang menekankan prinsip hidup berdampingan secara damai. Kedua ialah era 1960-an sehingga 1970-an yang menyaksikan kemerosotan dan ketegangan hubungan Malaysia dengan China. Ketiga sekitar tahun 1970-an sehingga 1980-an berlaku hubungan normalisasi Malaysia dengan. Keempat ialah tahun 1980an sehingga era globalisasi yang menyaksikan peningkatan hubungan Malaysia dengan China.

Ketika era 1950-an dasar luar Malaysia terhadap China ialah anti-China dan antikomunisme. Antara faktor yang menyebabkan Malaysia bermusuhan dengan China kerana dipengaruhi oleh persaingan dua blok iaitu blok demokrasi dan blok komunis. Sokongan Malaysia terhadap demokrasi tidak berbelah bahagi dan menentang sekerasnya negara dan fahaman komunisme seperti Kesatuan Soviet dan China. Tindakan dan pendirian Malaysia yang condong ke arah Barat kerana negara bergantung kepada bantuan ekonomi, perdagangan dan keselamatan daripada Amerika Syarikat dan Britain.5 Walaupun demikian pada 31 Mei 1974, ketika Parti Komunis Malaya (PKM) aktif menyebarkan fahaman ideologi komunis dengan bantuan Parti Komunis China (PKC), Abdul Razak merintis hubungan normalisasi dengan China.6 Kesatuan Soviet pada tahun 1989 menandakan berakhirnya Perang Dingin. Pada masa yang sama Parti Komunis Malaya (PKM) menyerahkan senjata dan China juga menghentikan segala propaganda terhadap Malaysia. Peristiwa tersebut meningkatkan hubungan dua hala Kuala Lumpur-Beijing dalam hal ehwal politik antarabangsa, sektor perdagangan, pelaburan, sains dan teknologi yang tidak pernah berlaku sebelum ini. Abdullah dan Najib juga secara konsisten meningkatkan kepercayaan dan menolak teori ancaman China.

Artikel ini menghujahkan tiga persoalan iaitu apa faktor-faktor yang mempengaruhi dasar luar Malaysia terhadap China, bagaimana faktor-faktor tersebut memberikan implikasi yang signifikan kepada penstrukturan dasar luar Kuala Lumpur terhadap Beijing dan yang ketiga mengapa Malaysia menjalinkan kerjasama dengan China sedangkan Beijing konsisten memberikan ancaman kepada Kuala Lumpur. Bagi mendapatkan hasil kajian yang koheren, kajian mengaplikasikan teori neoklasikal realisme dan konsep grand strategy. Kajian juga membahagikan tiga tempoh masa bagi menganalisis faktor yang signifikan dalam pembentukan dasar luar Kuala Lumpur ke atas Beijing iaitu 1957-1990, 1990-2003 dan 20032018.

Data dan maklumat sekunder diperolehi melalui kajian perpustakaan seperti buku dan artikel berkaitan hubungan antarabangsa, jurnal hubungan antarabangsa yang mempunyai perbahasan kritikal dan komprehensif yang meliputi isu mengenai kebangkitan kuasa China, hubungan Malaysia terhadap China, dasar luar luar China terhadap rantau Asia Tengara pasca Perang Dingin, dasar luar dan domestik negara Malaysia dan China, isu keselamatan rantau Asia Tenggara, hubungan strategik antara Amerika Syarikat dan China di kepulauan Spratly.

\section{Teori Realisme Neoklasikal}

Teori neoklasikal realisme diaplikasikan bagi menerangkan gabungan faktor struktur antarabangsa, domestik dan individu dalam penstrukturan dasar luar sesebuah negara. Faktor struktur antarabangsa tidak boleh berdiri sendiri dalam menerangkan secara total sinergi penstrukturan dasar luar sesebuah negara, begitu juga dengan faktor domestik dan individu.7

5 Azizan I, "Peranan dan Pengaruh Tunku Abdul Rahman dalam Sejarah Sasar Luar Negara: Tahun-tahun Awalan 1957-1962," Jebat, Vol.18, 1990, hlm. 234.

6 J. Saravanamuttu, Malaysia's Foreign Policy, the First Fifty Years: Alignment, Neutralism, Islamism, Institute of Southeast Asian Studies, Singapore, 2010.

7 G. Rose, "Neoclassical Realism and Theories of Foreign Policy." World Politics 5 (1), October 1998, hlmn. 144-177. 
Sistem antarabangsa yang berbentuk anarki adalah berbeza dengan suasana politik domestik. Kerajaan mempunyai kuasa untuk memonopoli rakyat dengan memaksa mereka untuk mengikut segala arahan dan dasar yang dilakukan tetapi di peringkat politik antarabangsa tidak ada mana-mana negara yang boleh memaksa negara lain. Hal ini kerana setiap negara mempunyai kedaulatan dan kebebasan dalam setiap tindakan yang dilakukan dan diimplementasikan.

Kecanggihan teknologi ketenteraan dan bilangan senjata nuklear yang banyak berbanding dengan negara-negara yang lain tidak cukup untuk menerangkan kekuatan sesebuah negara. Siapa dan bagaimana faktor-faktor tersebut digunakan untuk melindungi diri dan memberikan ancaman kepada negara lain juga signifikan dalam mengukur kekuatan sesebuah negara. Definisi kuasa dan kekuatan sesebuah negara juga ditentukan oleh pemimpin kerana persepsi dan tindakan pemimpin juga memberikan impak yang signifikan berbanding kemampuan fizikal sesebuah negara. Rose berhujah bahawa the consequence is that the options in foreign policy presented to the political leadership can be diminished because of how they perceive the situation in hand.8 Oleh itu teori neoklasikal merupakan sebuah teori yang menganalisis dasar luar sesebuah negara berdasarkan faktor struktur antarabangsa, domestik dan individu.

\section{Grand Strategy}

Dasar luar yang dibentuk merupakan grand strategy untuk keselamatan dan kepentingan nasional sesebuah negara. Grand strategy merupakan strategi tertinggi yang terdiri daripada ketenteraan, ekonomi, alam sekitar dan sebagainya. Grand strategy diaplikasikan oleh semua negara tidak kira kuasa besar mahupun lemah kerana sumber ancaman dan matlamat bagi kuasa besar dan kecil adalah tidak sama.9 Kelangsungan kuasa besar dalam pentas politik antarabangsa ialah mengekalkan atau berusaha untuk mencapai status sebagai kuasa unggul yang tidak mampu ditandingi oleh mana-mana kuasa yang lain.10 Namun demikian pada abad ke-21, peperangan bukan lagi grand strategy utama kepada kuasa-kuasa besar seperti Amerika Syarikat dan China untuk memperluaskan kuasa dan mengekalkan status. Sebaliknya mereka menjalankan dasar berbaik-baik dengan negara-negara kecil melalui bantuan kewangan, isu hak asasi manusia, alam sekitar dan sebagainya.11

Bagi negara-negara yang sedang membangun dan kecil seperti Malaysia, Filipina dan Vietnam, fokus utama grand strategy mereka lebih kepada pembangunan ekonomi, isu-isu alam sekitar, masalah kesihatan berbanding isu ketenteraan.12 Tidak dinafikan bahawa penglibatan negara-negara kecil di dalam isu-isu global adalah terhad kerana tidak boleh memberikan implikasi yang besar seperti kuasa-kuasa besar. Walaupun demikian kuasa-kuasa tersebut menjalankan sebuah dasar yang bebas dan dinamik kerana mereka mempunyai autonomi dalam penstrukturan dasar luar mereka tanpa dikawal oleh mana-mana pihak. Sebagai contoh Malaysia ketika pemerintahan Abdullah menerima pinjaman daripada China sebanyak USD\$800 juta untuk membina Jambatan Kedua Pulau Pinang. Selain itu Malaysia dan China juga telah menandatangani sebuah memorandum persefahaman (MoU) berkenaan

\footnotetext{
${ }_{8}$ G. Rose, "Neoclassical Realism and Theories of Foreign Policy." World Politics 5 (1), October 1998, hlmn. 147. 9 J. W. Taliaferro, Steven E. Lobell, and Norrin M Ripsman, Neoclassical Realism, the State and Foreign Policy, Cambridge University Press, 2009.

10R. Koehane, After Hegemony: Cooperation and Discord in the World Political Economy, Princeton University Press, 2005.

11 M. Beckley, “The Power of Nations: Measuring What Matters,” International Security, 43 (2), 2018.

12 A. Ko, Not for political domination: China's Foreign Economic Policy towards Vietnam, Singapore and Malaysia in the Open Era. Disertasi Ph.D. University of Glasgow, 2010.
} 
kerjasama pertahanan.13 Pada masa yang sama Amerika Syarikat pula membekalkan kelengkapan radar yang dianggarkan bernilai USD\$20 juta kepada Malaysia.14 Gambaran jelas adaptasi paradigma neoklasikal realisme dan grand strategy digunakan seperti gambar rajah 1.1 digunakan pertalian di antara China dan Malaysia.

Gambar Rajah 1.1 merupakan perkaitan ketiga-tiga faktor iaitu faktor struktur antarabangsa, domestik dan individu kepada evolusi perubahan dasar luar Malaysia terhadap China. Faktor struktur antarabangsa ialah hubungan dan interaksi antara Amerika Syarikat dengan China yang mempengaruhi pendirian dan tindakan dasar luar Malaysia terhadap China. Faktor domestik pula suasana politik domestik. Faktor individu terdiri daripada peranan yang dimainkan oleh barisan pemimpin elit. Bagi mendapat analisis yang analitikal antara hubungan angkubah bebas dan angkubah bersandar, penglibatan dan kerjasama antara China dengan ASEAN merupakan angkubah pengantara yang menjelaskan lagi pilihan dan tindakan kepada perubahan dasar luar Malaysia terhadap China selama enam dekad yang dibahagikan kepada tiga bahagian iaitu pada tahun 1957-1990, 1990-2003 dan 2003-2018. Dalam bahagian yang seterusnya, ketiga-tiga fasa tersebut dianalisis melalui faktor struktur antarabangsa, faktor domestik dan faktor individu.

\section{Gambar Rajah 1.1: Adaptasi daripada Model Neoklasikal Realisme dan Grand Strategy}

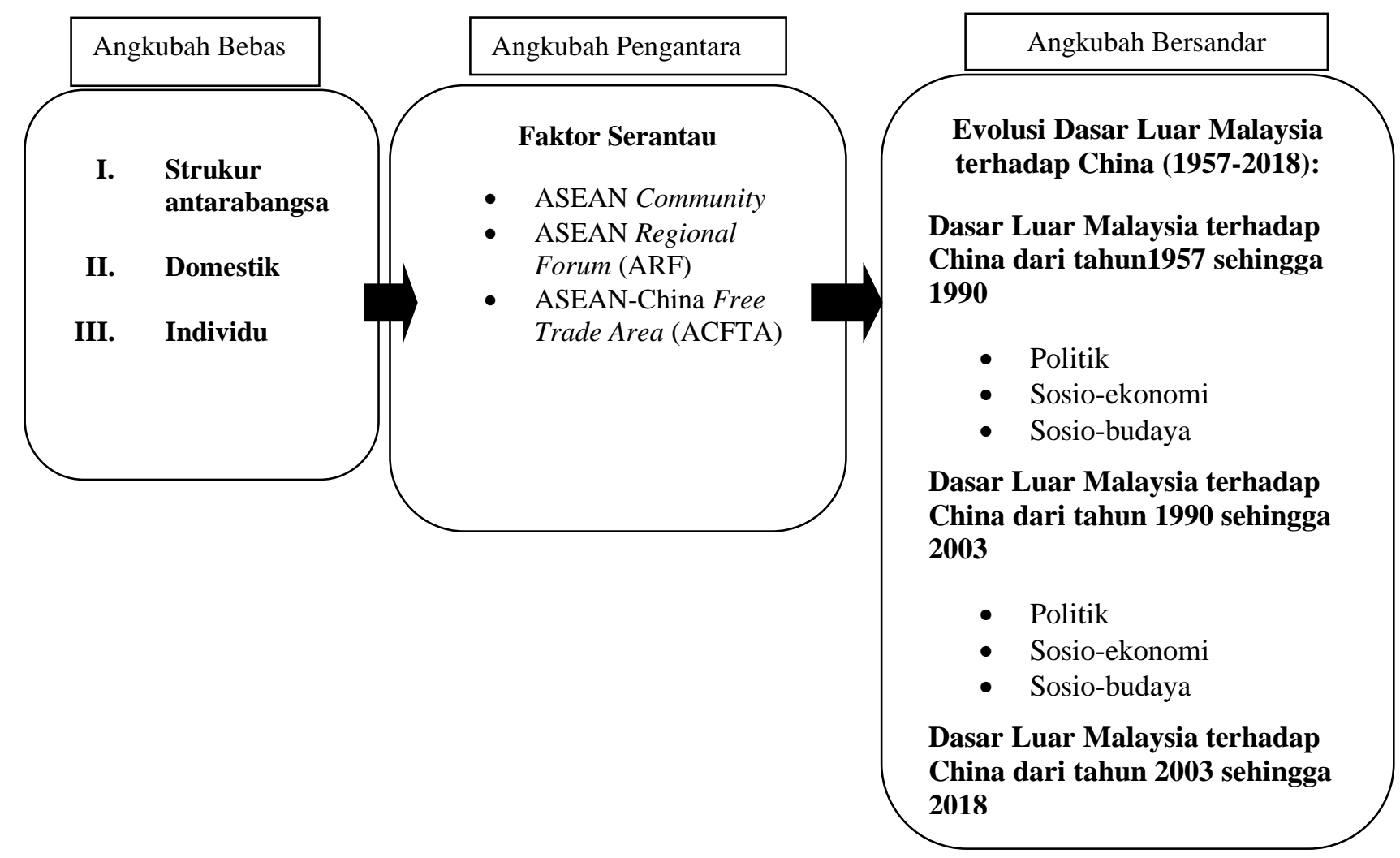

Sumber: Disentesiskan oleh pengkaji

13 Kuik.C.C, “Analyzing Malaysia's Changing Alignment Choices,” 1971-89. Jebat. Vol. 37, 2010, hlm. 41-74. 14 R. D. Kaplan, Asia's Cauldron: The South China Sea and the End of a Stable Pacific, Random House, 2014, hlmn. 15. 


\section{Era Konflik Sehingga Normalisasi (1957-1990)}

China merupakan sekutu kuat Kesatuan Soviet yang berada di luar blok barat. Kedudukan geografi China secara langsung berjiran dengan hampir 14 buah negara di sempadannya seperti Mongolia, Kazakhstan, India dan Pakistan manakala 6 buah negara di kawasan sempadan lautan seperti Jepun, Malaysia dan Indonesia. Situasi tersebut menyebabkan Amerika Syarikat bimbang berlakunya kesan domino apabila satu persatu negara kapitalis jatuh ke tangan komunis seperti yang berlaku di Semenanjung Korea dan Vietnam. Maka, tidak hairanlah apabila Amerika Syarikat cuba memulaukan China daripada politik antarabangsa, menjalankan sekatan ekonomi dan tidak mengiktiraf Republik Rakyat China (RRC) sebagai sebuah negara yang sah.

Malaysia juga mengambil tindakan yang sama iaitu tidak mengiktiraf dan menolak sebarang hubungan dengan negara komunis seperti China. Selain daripada menyokong Amerika Syarikat, Kuala Lumpur tidak menjalinkan sebarang hubungan dengan China juga disebabkan peristiwa Konfrontasi. Konfrontasi Indonesia terhadap Malaysia pada tahun 1963 boleh disimpulkan sebagai didalangi oleh Parti Komunis China (PKC). Indonesia dan RRC tidak bersetuju dengan penubuhan Malaysia pada16 September 1963 yang terdiri daripada Malaya, Singapura, Sabah dan Sarawak. Kedua-dua buah negara tersebut menolak pembentukan tersebut kerana mereka berpendapat ia sebuah bentuk penjajahan baharu dan alat kepada Barat. Ketika Perang Vietnam pula iaitu pada tahun 1959-1975, Mao memberikan bantuan kewangan sebanyak 320 juta yuen, 320 ribu orang tentera, 270 ribu senapang dan lebih daripada 2 juta jenis peluru dan senapang kepada Vietnam Utara dalam menghadapi serangan daripada Vietnam Selatan. 15 Pada masa yang sama dasar negara China memberi bantuan adan pengawasan terhadap overseas Chinese, menyebabkan para pemimpin Melayu berasa ragu dengan kesetiaan kaum Cina di Malaya.16 Kesemua faktor tersebut menyebabkan Tunku menolak mengadakan hubungan dengan China dan terus menjalankan dasar anti-China dan anti-komunis.

Walaupun demikian pada tahun 1974, Malaysia mengubah dasar luarnya daripada dasar pengasingan kepada dasar luar yang bebas dan neutral. Salah satu faktor yang meyumbang kepada perubahan ini adalah kerana kerana Amerika Syarikat menormalisasikan hubungannya dengan China pada tahun 1972. Maka tidak hairan apabila pada 31 Mei 1974, Malaysia secara rasminya menjalinkan hubungan rasmi dengan China. Sebelum Malaysia menjalinkan hubungan normal dengan China, Malaysia terlebih dahulu menjalinkan hubungan diplomatik dengan negara-negara komunis lain seperti Kesatuan Soviet pada April 1967, Poland pada Jun 1971 dan Korea Utara pada Jun 1973.17 China merupakan negara komunis terakhir Malaysia mengadakan hubungan diplomatik. Antara faktor kenapa demikian adalah kerana isu Parti Komunis China (PKC) mempunyai hubungan secara terus dengan Parti Komunis Malaya (PKM). Selain itu kedudukan geografi China yang merupakan salah satu jiran paling hampir dengan Malaysia juga menyebabkan RRC negara komunis terakhir Malaysia menjalinkan hubungan normalisasi. Walaupun Wisma Putra bertanggungjawab merangka sebuah strategi yang berhati-hati dan mengadaptasi sebuah dasar yang dinamik agar tidak menjejaskan keselamatan dan kedaulatan negara tetapi pada masa yang sama Kuala Lumpur memperoleh manfaat hasil daripada hubungan bilateral tersebut.

Antara faktor yang mengubah dasar luar Malaysia terhadap China ialah penarikan keluar tentera Amerika Syarikat dan Britain dari rantau Asia Tenggara. Penarikan keluar

${ }_{15}$ Chen Jian, "China's Involvement in the Vietnam War," 1964-69, The China Quarterly, Vol. 42, June 1995, hlmn. 359.

16 Lauren C, The Ethnic Chinese Variable in Domestic and Foreign Policies of Malaysia and Indonesia. Disertasi Universiti Simon Fraser, 1995.

17 Kementerian Luar Negara, https://www.kln.gov.my/web/guest/foreign-policy. 
tentera Amerika Syarikat dan Britain menyebabkan wujudnya kelompangan kuasa di rantau tersebut. Selain itu, hubungan normalisasi dilakukan demi kelangsungan Parti Perikatan khususnya ketika Pilihan Raya 1974. Kekalahan besar Parti Perikatan dalam Pilihan Raya 1969 disebabkan parti pemerintah kehilangan majoriti sokongan daripada kaum Cina. Ketika hubungan normalisasi dijalankan, Parti Perikatan berjaya meraih sokongan undi daripada kaum Cina dan menang besar ketika Pilihan Raya 1974.18

Sejak tahun 1974 sehingga tahun 1980-an kerjasama Malaysia dengan China hanya tertumpu kepada aspek ekonomi sahaja walaupun sudah hampir 10 tahun kedua-dua buah menjalinkan hubungan normalisasi. Analisis mendapati situasi tersebut berlaku kerana China masih lagi dijangka oleh kerajaan Malaysia memberikan bantuan kepada PKM. Beijing juga masih mengiktiraf dwi kenegaraan kepada rakyat China yang berada di luar negara walaupun sudah berjanji tidak akan melakukannya. Ketika Deng mengadakan lawatan ke Malaysia pada akhir tahun 1983, beliau memberikan jaminan untuk tidak mengiktiraf dwi kenegaraan rakyat China yang berhijrah ke negara-negara lain sekali gus meminta kaum Cina di Malaysia taat setia kepada pemerintah.19 Pimpinan malaysia ketika itu tidak mahu China campurtangan dalam hal ehwal Malaysia kerana ia akan menghalang pembinaan negara bangsa di Malaysia. Sedar akan tekanan Malaysia, China mengambil inisiatif melalui China Travel Service yang beribu pejabat di Hong Kong menolak sebarang permohonan kaum Cina Malaysia yang ingin melancong ke China tanpa mendapat kebenaran daripada Kuala Lumpur.20 Oleh disebabkan itu walaupun Malaysia mengadakan hubungan normalisasi dengan China, Kuala Lumpur masih lagi berasa bimbang dan syak wasangka terhadap tindakan Beijing sehinggalah perang dingin berakhir yang akan dianalisis dalam bahagian seterusnya.

Faktor individu juga memberikan impak kepada penstrukturan dasar luar Malaysia terhadap China. Tunku tidak menjalankan sebarang hubungan dengan China kerana latar pendidikan beliau dari Barat. Disebabkan itu, beliau lebih selesa menjalankan sebarang urusan dengan negara-negara Barat berbanding dengan negara-negara lain.21 Tunku mengundi menolak kerusi China ketika Persidangan Persatuan Bangsa-Bangsa Bersatu dan menyokong Taiwan berkerajaan sendiri.22 Pengalaman Abdul Razak melalui era Perang Dingin menyebabkan beliau melaksanakan dua strategi utama dalam dasar luar iaitu yang pertama mengadakan hubungan persahabatan dengan semua negara tanpa mengira fahaman ideologi dan yang kedua ialah menyokong kerjasama serta persefahaman dalam kalangan negara dunia ketiga. Strategi ini memberi inisiatif kepada beliau untuk membentuk dasar luar Malaysia yang lebih peka dan sensitif kepada perubahan yang berlaku di dalam sistem antarabangsa. Melalui pengalaman konfrontasi, darurat dan sikap Tunku yang berpihak kepada Barat banyak memberikan panduan dan pengajaran kepada pemimpin seterusnya dalam membentuk dasar luar Malaysia yang lebih dinamik dan terbuka. Mahathir menganggap China pada awalnya merupakan ancaman jangka panjang kepada rantau kesan daripada penglibatan China dalam konflik di Indochina, Laut China Selatan dan hubungan China dengan PKM walaupun negara komunis tersebut berjanji untuk memutuskan hubungan dengan gerakan insurgensi tersebut sejak tahubn 1974. Walaubagaimanapun pada tahun 1985 Mahathir mula menunjukkan

18 D. Mauzy, Barisan Nasional: Coalition Government in Malaysia, Marican \& Sons (Malaysia), 1983, hlm.9596.

${ }_{19}$ Lee Lai To, “Deng Xiaoping's ASEAN Tour: A Perspective on Sino-Southeast Asian Relations, ” Contemporary Southeast Asia, 3 (1), 1981, hlmn. 64.

20 L. Suryadinata, Southeast Asia's Chinese Businesses in an Era of Globalization, ISEAS-Yusof Ishak Institute, 2006, hlmn.84.

21 Ito Mitsuomi, “The Path To Malaysia’s Neutral Foreign Policy In The Tunku Era”, Sarjana, 30 (2), 1995, hlmn. 84.

22 J. Saravanamuttu, Malaysia's Foreign Policy: The First Fifty Years: Alignment, Neutralism, Islamism, Institute of Southeast Asian Studies, Singapore, 2008, hlmn 52-53. 
persepsi positif terhadap China akibat dipengaruhi oleh kepentingan ekonomi dan perdagangan yang menjadi keutamaan utama dasar luar Malaysia pada masa itu.

\section{Era Kedinamikan dan Pembangunan Kerjasama Bilateral (1990-2003)}

Berakhirnya Perang Dingin pada tahun 1989 membentuk sebuah pola baharu terhadap sistem politik antarabangsa. Kemenangan Amerika Syarikat dalam membentuk order baharu dunia meyakinkan komuniti antarabangsa sebuah sistem ekonomi bebas dan adil tanpa tekanan daripada mana-mana pihak. Ironinya perkara tersebut tidak berlaku kerana Washington menjalankan dominasi, eksploitasi dan dasar berat sebelah terhadap negara-negara kecil. Sebagai contoh dasar Volker Shock, kempen American Soybean Association dan pembentukan blok-blok perdagangan seperti North American Free Trade Agreement (NAFTA) dan sokongannya terhadap European Community (EU). Tekanan dan tindakan Amerika Syarikat menyebabkan berlaku ketidakseimbangan dan penindasan produk-produk tempatan sehingga menjejaskan ekonomi Malaysia. 23

Akibat peristiwa tersebut, Malaysia mengusulkan penubuhan sebuah blok ekonomi iaitu East Asian Economic Group (EAEG) yang terdiri daripada ASEAN, Jepun, Korea Selatan, dan China bertujuan untuk mengekang monopoli Washington. China menyambut baik usaha Mahathir, namun sokongan yang diberikan hanya retorik semata-mata kerana berlaku rundingan untuk memasukan negara tersebut sebagai ahli World Trade Organisation (WTO).24 Walaupun begitu, ketika Malaysia mencadangkan sekali lagi sebuah blok ekonomi iaitu East Asia Economic Caucus (EAEC), Perdana Menteri China ketika itu Li Peng menyatakan sokongan penuh dan berjanji akan meyakinkan negara-negara Asia untuk menyertai EAEC.

Perubahan tindakan Beijing disebabkan kewujudan Asia Pacific Economic (APEC) yang memberikan kesan negatif kepada perkembangan ekonomi di Asia.25 Sokongan China terhadap cadangan Malaysia melalui EAEG dan EAEC menunjukkan mula berlaku peningkatan kerjasama politik di peringkat rantau dan antarabangsa. Walaupun berlaku peningkatan hubungan bilateral Kuala Lumpur masih berhati-hati dengan Beijing khususnya mengenai isu di Laut China Selatan. Hal ini kerana negara China mengadakan latihan ketenteraan secara besar-besaran di kepulauan tersebut sehingga mewujudkan keadaan tidak selamat dan curiga. Bagi mengelakkan ketegangan dengan China, Mahathir menegaskan berdasarkan sejarah peradaban, Beijing tidak pernah menjajah mana-mana negara.26 Tindakan tersebut dilakukan untuk mengelakkan sebarang campur tangan daripada Amerika Syarikat dan memantapkan lagi kerjasama dengan China demi manfaat ekonomi negara.

Peningkatan hubungan kedua-dua buah negara ini juga disebabkan perubahan dan keadaan yang berlaku di peringkat domestik. Berakhirnya Perang Dingin menyaksikan perletakkan senjata PKM. Pada masa yang sama tiada lagi kemunculan isu kesetiaan kaum Cina Malaysia kerana ramai daripada mereka sedar kedudukan mereka di Malaysia adalah tetap. Selain itu, krisis politik United Malays National Organisation (UMNO) yang berlaku pada tahun 1987 dan kelembapan ekonomi juga antara faktor peningkatan hubungan bilateral Kuala Lumpur-Beijing. Krisis politik UMNO melibatkan pergaduhan Tengku Razaleigh (Menteri Perdagangan dan Industri), dan Musa Hitam (Timbalan Perdana Menteri) ketika itu

\footnotetext{
23 Kuik.C.C. “Analyzing Malaysia’s Changing Alignment Choices, 1971-89,” Jebat, Vol 37, 2010, hlmn 41-74. ${ }_{24}$ C. Jeshurun, Fifty Years of Diplomacy, The Other Press, 2007, hlmn. 231.

25 Mohd Ikbal bin Huda, "Japan's Responses to China's Economic Incentives and Initiatives towards ASEAN," International Journal of East Asian Studies, 1 (1), 2017, hlmn 4-5.

26 Poon Kim Shee, "The Political Economy of Mahathir's China Policy: Economic Cooperation, Political and StrategicAambivalence," Ritsumeikan Annual Review of International Studies, Vol. 3, 2004, hlmn 68.
} 
yang ingin merebut jawatan tertinggi dalam UMNO kerana ketidakupayaan Mahathir membaik pulih ekonomi negara.27

Kelembapan ekonomi yang berlaku bukan sahaja mewujudkan krisis di kalangan elit politik tetapi turut melibatkan pergeseran antara pemimpin dengan para usahawan bumiputera yang bergantung kepada kerajaan.28 Mahathir mengembalikan keyakinan semua pihak dengan memberi persepsi bahawa China dikenal pasti sebagai sebuah negara yang berpotensi besar untuk menjadi rakan dagang baharu kerana limpahan ekonomi negara tersebut. China juga berjanji untuk meningkatkan penyertaan bumiputera dalam kerjasama bilateral perdagangan dan pelaburan yang dahulunya hanya dimonopoli oleh usahawan-usahawan Cina Malaysia.29 Sepanjang era 1990-an berlaku perkembangan yang signifikan hubungan kedua-dua buah negara yang tidak pernah berlaku sebelum ini. Sebagai contohnya Perjanjian Kerjasama dalam Bidang Sains dan Teknologi ditandatangani dan kemuduannya delegasi usahawan dan ahli perniagaan Malaysia melawat ke Beijing untuk menandatanganipelbagai Memorandum of Understanding (MoU) yang akhirnya menjadikan China salah satu rakan dagang Malaysia yang terpenting.

Selain daripada faktor antarabangsa dan faktor domestik, faktor individu juga penting dalam menganalisis dasar luar Malaysia terhadap China. Pada awalnya Mahathir berasa curiga terhadap China tetapi selepas negara komunis tersebut mengalami pertumbuhan ekonomi yang pesat pada era 1990-an, beliau menukar pendirian dan perspektifnya terhadap Beijing. Mahathir menolak teori ancaman China seperti yang digembar-gemburkan oleh Barat. Beliau juga menjemput China untuk menyertai gerakan dan aktiviti Association of Southeast Asian Nations (ASEAN). Mahathir merasakan bahawa sekiranya China menjadi lebih terbuka, ia akan membawa faedah kepada semua negara anggota ASEAN. Ketika ahli-ahli negara ASEAN merasakan bimbang terhadap tindakan China ke atas Laut China Selatan, di Selat Taiwan dan peningkatan kuasa ekonomi China; Mahathir menegaskan bahawa 'we do not look at China as our potential enemy. We look at China as a country which has a great potential for becoming an economic power.' 30

\section{Era Pengukuhan Kerjasama dan Strategik (2003-2018)}

Tahun 2001 menyaksikan persaingan antara Amerika Syarikat dengan China apabila Washington mengubah pendirian terhadap rantau Asia Tenggara daripada benign neglect kepada second front.31 Ini bermaksud Washington mengambil keputusan untuk memperkuatkan dominasinya di rantau tersebut apabila berhadapan dengan China yang agresif. Antara faktor yang menyebabkan Amerika Syarikat mengubah dasar luarnya kerana kemerosotan pengaruh dan prestij negara tersebut di rantau Asia Tenggara. Hal ini kerana penyertaan China dalam WTO meningkatkan perkembangan sinergi ekonomi negara tersebut sehingga menjadi salah sebuah kuasa ekonomi dunia. Sebagai contohnya, Keluaran Dalam Negara Kasar (KDNK) Beijing berkembang dengan pesat daripada AS $\$ 362$ bilion pada tahun 1978 kepada AS\$13.7 trilion pada tahun 2004 dan terus meningkat kepada AS\$24.7 trilion pada tahun 2007. Ia merupakan perkembangan yang terbesar dalam sistem ekonomi

27 J. Saravanamuttu, Malaysia's Foreign Policy: The First Fifty Years: Alignment, Neutralism, Islamism, Institute of Southeast Asian Studies, 2008, Singapore.

28 H. Crouch, Government and Society in Malaysia, Princeton university Press, 1996, hlmn 115.

29 A. Ko, Not for Political Domination: China's Foreign Economic Policy Towards Vietnam, Singapore and Malaysia in the Open Era. Disertasi Ph.D. University of Glasgow, 2010, hlmn 262.

30 Abdul Razak Baginda, 'Malaysian Perceptions of China: From Hostility to Cordiality,' dalam Herbert Yee and Ian Storey, eds, The China Threat: Perceptions, Myths and Reality, Routledge Curzon, London, 2002, hlmn. 242. 31 Andrew Tan, Security Strategies in the Asia-Pacific: The United States' "Second Front" in Southeast Asia, Palgrave Macmillan, 2011, hlmn. 179. 
antarabangsa.32 Situasi tersebut menyebabkan 20 buah negara jirannya meningkatkan hubungan dengan China. Pada tahun 2011 berlaku pertembungan kuasa lunak antara Amerika Syarikat dengan China apabila Washington menjalankan dasar Asia Pivot dan China pula One Belt, One Road (OBOR). Kedua-dua dasar tersebut bertujuan untuk memperluaskan kerjasama dengan negara-negara di Asia Tenggara dalam bidang perdagangan, pelaburan, pembangunan infrastruktur dan sebagainya. Selain daripada persaingan ekonomi, isu di Laut China Selatan juga menyaksikan persaingan kedua-dua buah kuasa besar. China meningkatkan latihan ketenteraan dan menempatkan dua unit artileri di kawasan perairan Spratly. Tambahan pula, senjata-senjata berat dihalakan ke arah kawasan maritim yang turut menjadi kawasan tuntutan Vietnam dan Filipina. Tindakan China mewujudkan kebimbangan kepada Amerika Syarikat. Refleksi daripada tindakan tersebut, Washington menghantar dua buah kapal perang dan pesawat tentera ke kawasan tuntutan bertindih di Laut China Selatan.

Peristiwa tersebut mengubah dan menstrukturkan semula dasar luar Malaysia melalui dasar yang lebih berhati-hati dan dinamik untuk keselamatan nasionalnya. Abdullah dan Najib mengadaptasikan dasar luar yang berbentuk equidistance dan hedging vis-à-vis dengan keduadua kuasa besar tersebut. Ketika era Abdullah, Malaysia menggunakan ASEAN sebagai batu loncatan untuk mengimbangi kuasa-kuasa besar di rantau Asia Tenggara. Abdullah mencadangkan penubuhan East Asia Summit (EAS) sebuah organisasi kerjasama ekonomi dan keselamatan. Cadangan penubuhan EAS menerima sokongan padu bukan sahaja daripada negara ahli ASEAN dan China, tetapi turut mendapat sokongan Amerika Syarikat, Australia dan New Zealand.33 Hal ini merupakan sebuah kejayaan besar kepada negara, kerana sebelum ini usaha Malaysia untuk menubuhkan EAEG dan EAEC tidak berjaya kerana mendapat tentangan hebat bukan sahaja daripada Amerika Syarikat malah daripada negara anggota ASEAN sendiri. Sewaktu pentadbiran Najib, Malaysia mengambil pendekatan dengan mengeratkan kerjasama ketenteraan dengan kedua-dua buah negara. Sebagai contoh, pada tahun 2012, Malaysia meningkatkan kerjasama dengan Amerika Syarikat melalui latihan maritim iaitu Cobra Gold, dan pada tahun yang sama juga berlaku rundingan antara Kuala Lumpur dengan Beijing dalam usaha menginstitusikan kerjasama ketenteraan.34 Pilihan dan jajaran Malaysia mengelakkan terperangkap dengan persaingan Amerika Syarikat dan China.

Limpahan ekonomi China memberikan kesan signifikan bukan sahaja kepada sinergi pertumbuhan ekonomi Malaysia tetapi juga kepada keharmonian masyarakat berbilang kaum. Ketika era Abdullah Badawi, syarikat-syarikat milik kerajaan seperti Sime Darby dan Petronas bergiat aktif menjalinkan kerjasama dengan syarikat-syarikat daripada China dan memberikan impak yang besar kepada ekonomi negara berbanding era Mahathir. Sebagai contoh, Sime Darby memeterai MoU dengan Weifang Municipal Port and Navigation Bureau dalam Projek Terminal Pelabuhan, kerjasama daripada syarikat-syarikat milik kerajaan dengan Beijing memberikan keseimbangan kepada ekonomi multietnik Malaysia. Hal ini kerana hasil limpahan ekonomi kuasa besar tersebut bukan hanya diraih oleh masyarakat Cina sahaja tetapi turut dirasai oleh masyarakat bumiputera di negara ini.35 Barisan Nasional (BN) buat pertama kalinya kehilangan 2/3 kerusi di Dewan Rakyat sejak kemerdekaan pada tahun 1957. Walaupun berlaku peningkatan ekonomi Malaysia melalui hubungan baik dengan China, namun ia tidak mampu menangani krisis kewangan global dan krisis kejatuhan wang ringgit.

\footnotetext{
32 Jin Zhesong dan Li Jun, Foreign Trade Growth and Economic Development in China: Retrospective and Future Prospects, Enrich Professional Publishing, Beijing, 2011.

33 Kuik, C. C, Analyzing Malaysia's Changing Alignment Choices, 1971-89. Jebat, Vol 37, 2010, hlm. 41-74. 34 Kuik C. C. dan G. Rozman, "Introduction to Part 1: Light or Heavy Hedging: Positioning between China and the United States," dalam Gilbert Rozman, Joint U.S.-Korea Academic Studies 2015, Vol. 26, Korea Economic Institute of America, Washington DC, 2015, hlmn. 1-9.

35 Kuik, C. C, "Making Sense of Malaysia's China Policy: Asymmetry, Proximity, and Elite's Domestic Authority," Chinese Journal of International Politics, Vol. 6, 2013, hlmn. 429-467.
} 
Oleh itu, Najib Tun Razak memperluaskan lagi kerjasama dengan China ketika beliau mengambil alih tampuk kepimpinan daripada Abdullah untuk menambat hati semula rakyat. Antara bentuk kerjasama antara Kuala Lumpur-Beijing ialah Pelan Tindakan Bersama Mengenai kerjasama strategik antara kerajaan Malaysia dengan Republik Rakyat China (RRC), Perjanjian Penghapusan Sebahagian Keperluan Visa bagi pemegang pasport diplomatik dan pegawai kedua-dua buah negara, Perjanjian Kerjasama dalam bidang sains dan teknologi marin, dan memorandum meningkatkan kerjasama antara Pos Malaysia dengan Pos China.

Ketika era Abdullah dan Najib, faktor individu mendominasi dalam memandu pembentukan dasar luar Malaysia terhadap China. Kedua-dua orang pemimpin menjalankan sebuah dasar yang tidak hanya statik dan condong ke arah mana-mana kuasa-kuasa besar dalam mewujudkan positive sum game. Selain itu analisis turut mendapati bahawa Abdullah dan Najib mengimplementasikan dasar playing the field dengan memaksimumkan segala bentuk strategi seperti pengimbangan, perlindungan nilai dan pakatan terhadap China mahupun Amerika Syarikat demi kelangsungan negara. Pengalaman ketika era Perang Dingin banyak memberi pengajaran kepada penstrukturan dasar luar Malaysia. Hal ini penting bagi memastikan Malaysia menjadi rakan diplomasi dan strategik yang boleh dipercayai bukan sahaja China tetapi juga Amerika Syarikat lebih-lebih lagi kedua-dua buah kuasa besar ini sering mengimbangi satu sama lain.

\section{Hasil Kajian}

Secara keseluruhannya, kronologi dasar luar Malaysia terhadap China dari tahun 1957 sehingga tahun 2018 dibahagikan kepada tiga fasa iaitu 1957-1990, 1990-2003, dan 20032018. Ketiga-tiga fasa dianalisis melalui faktor struktur antarabangsa, faktor domestik dan faktor individu. Sepanjang tahun 1957 sehingga tahun 1990, faktor struktur antarabangsa mendominasi perubahan dasar luar Malaysia terhadap China. Ketika awal kemerdekaan, Malaysia tidak mengadakan hubungan dengan China disebabkan perubahan dan tekanan yang berlaku ketika era Perang Dingin. Namun demikian pada tahun 1974, Malaysia mula mengadakan hubungan normalisasi dengan China. Perubahan daripada anti-China kepada hubungan normalisasi disebabkan penarikan keluar tentera Amerika Syarikat dan Britain dari rantau Asia Tenggara, peningkatan kuasa China dan Amerika Syarikat menjalankan hubungan normalisasi dengan China. Pada era 1980-an menyaksikan kelembapan ekonomi dunia disebabkan kegawatan ekonomi Barat. Perkara ini secara tidak langsung memberikan kesan kepada ekonomi Malaysia kerana Barat merupakan rakan dagang utama. Oleh disebabkan itu Mahathir menjalankan Dasar Padang ke Timur untuk mengurangkan kebergantungan kepada Barat dan mencari rakan dagang baharu yang terdiri daripada negara China, Jepun dan Korea Selatan. Walaupun Malaysia mengadakan kerjasama ekonomi dengan China, namun Malaysia masih lagi menjalankan sebuah dasar yang pragmatisme kerana Perang Dingin belum berakhir dan gerakan insurgensi komunis juga masih lagi aktif.

Pada tahun 1990 sehingga tahun 2003, faktor domestik mendominasi kepada pembentukan dasar luar Malaysia terhadap China. Berakhirnya Perang Dingin menyebabkan berakhirnya juga gerakan PKM. China menghentikan segala sokongan dan bantuan kepada gerakan tersebut. Peristiwa tersebut merupakan salah satu faktor penolak kepada kerjasama yang lebih luas dan erat antara kedua-dua buah negara. Kelembapan ekonomi negara yang berpanjangan sepanjang era 1980-an menyebabkan krisis politik antara pemimpin elit dalam merebut jawatan nombor satu Malaysia. Krisis dalaman UMNO bukan sahaja melibatkan elit politik tetapi juga terdiri daripada para usahawan bumiputera yang merupakan ahli UMNO. Mahathir memperluaskan kerjasama dan hubungan dengan China daripada pelbagai sektor seperti perdagangan, pelaburan, sains dan teknologi dan sebagainya yang tidak pernah berlaku sebelum ini. Peningkatan hubungan dengan China bukan sahaja meningkatkan ekonomi negara 
tetapi membawa kemakmuran kepada masyarakat Malaysia yang berbilang kaum. Jaminan Beijing untuk meningkatkan penyertaan masyarakat Melayu dalam sebarang kerjasama perdagangan dan pelaburan yang dahulu hanya dimanfaatkan masyarakat Cina Malaysia sahaja. Namun begitu, faktor individu juga signifikan ketika era ini. Perubahan persepsi dan keyakinan Mahathir terhadap China iaitu daripada ancaman kepada rakan strategik membawa sinergi hala tuju baharu kepada hubungan bilateral kedua-dua buah negara.

Ketika tahun 2003 sehingga tahun 2018, faktor individu mendominasi kepada penstrukturan dasar luar Malaysia terhadap China. Abdullah dan Najib secara konsisten menolak teori ancaman China walaupun negara kuasa besar tersebut bertindak agresif di Laut China Selatan. Selain itu jajaran, pilihan dan tindakan Abdullah dan Najib yang menjalankan dasar luar equidistance dan hedging vis-à-vis terhadap China dan Amerika Syarikat merupakan sebuah tindakan yang bernas dan berhemah. Hal ini kerana berlaku persaingan antara keduadua buah kuasa besar tersebut di rantau Asia Tenggara. Oleh itu, Abdullah dan Najib menjalankan sebuah dasar dengan tidak memihak atau mengimbangi mana-mana kuasa besar untuk mengelakkan Malaysia daripada terperangkap daripada persaingan tersebut. Walaupun begitu, faktor domestik juga memberikan impak kepada penggubalan dasar luar Malaysia terhadap China. Kelembapan ekonomi, kejatuhan nilai mata wang dan kegagalan UMNO dalam mengekalkan 2/3 kerusi di Dewan Rakyat ketika PRU ke-13 menyebabkan Najib mengukuhkan kedinamikan integrasi kerjasama dengan China dalam usaha meningkatkan keyakinan rakyat kepada UMNO dan kerajaan di bawah kepimpinannya.

\section{Kesimpulan}

Secara keseluruhannya sepanjang evolusi dasar luar Malaysia terhadap China dari tahun 1957 sehingga tahun 2018, faktor struktur antarabangsa, faktor domestik dan faktor individu saling mempengaruhi satu sama dalam mencorak dasar luar Kuala Lumpur terhadap Beijing. Namun faktor struktur antarabangsa memberikan impak yang lebih tinggi dan signifikan berbanding faktor-faktor yang lain. Hal ini kerana tindakan dan hubungan antara kuasa-kuasa besar secara tidak langsung mewujudkan perubahan dalam struktur politik antarabangsa. Perubahan yang berlaku memberikan implikasi yang besar kepada keadaan dan keperluan domestik serta tindakan yang diambil oleh seseorang pemimpin dalam memastikan keselamatan dan kelangsungan negara.

Analisis juga mendapati kesan positif dasar luar Malaysia terhadap China daripada segi ekonomi, diplomatik dan sosio politik adalah hasil daripada grand strategy negara yang bijak dan efektif. Sepanjang tahun 1957 sehingga 2018 grand strategy Malaysia adalah mengadaptasi sebuah dasar yang seimbang dan tidak memihak dengan mana-mana kuasa besar. Kuik (2010) berhujah bahawa kebiasaannya sebuah negara kecil menjalankan kerjasama dengan kuasa-kuasa besar dalam bidang ketenteraan (Kuik 2010: 77). Walaupun demikian Malaysia menjalinkan kerjasama dengan kuasa-kuasa besar dalam bidang ekonomi bukan dalam bidang ketenteraan. Bagi kuasa-kuasa kecil pembangunan ekonomi adalah signifikan kepada kelangsungan negara.

\section{Rujukan}

Abdul Razak Baginda, 'Malaysian Perceptions of China: From Hostility to Cordiality,' dalam Herbert Yee and Ian Storey, eds, The China Threat: Perceptions, Myths and Reality, Routledge Curzon, London, 2002, hlmn. 242 227-47

Ayoob, A, The Third World Security Predicament: State making, Regional Conflict, and the International System, Lynne Rienner Publishers, United States, 1995. 
Azizan Idris, "Peranan dan Pengaruh Tunku Abdul Rahman dalam Sejarah Dasar Luar Negara: Tahun-tahun Awal 1957-1962," Jebat Vol 18, 1990, hlmn. 229-261.

Bahgaf, K, "Foreign Policy in the Third World: An Introduction," International Political Sciences Review, 5(1), 1984, hlm. 7-20.

Beckley, M, “The Power of Nations: Measuring What Matters," International Security, 43 (2), 2018, hlmn 7-44.

Carter, L, The Ethnic Chinese Variable in Domestic and Foreign Policies of Malaysia and Indonesia. Disertasi Universiti Simon Fraser, 1995.

Chung Chien Peng, "The Good Neighbour Policy in the Context of China's Foreign Relations," China: An International Journal 7(1), 2009, hlmn, 107-123.

Corbett, J, dan V. Wouter, Democracy in small states: Persisting against all odds, Oxford University Press, London, 2018.

Crouch, C, Government and Society in Malaysia, Princeton University Press, 1996.

Huntington, S, “Democracy Third Wave," Journal of Democracy 2(2), 1991, hlmn. 12-34.

Jeshurun, C, Fifty Years of Diplomacy, The Other Press, 2007.

Jian, J, "China Involvement in the Vietnam War, 1964-69", The China Quarterly, No. 142, 1995, hlm. 356-387.

Jin Zhesong dan Li Jun, Foreign Trade Growth and Economic Development in China: Retrospective and Future Prospects, Enrich Professional Publishing, Beijing, 2011.

Kaplan, R. D, R. D. Kaplan, Asia's Cauldron: The South China Sea and the End of a Stable Pacific, Random House, 2014.

Kementerian Luar Negara, https://www.kln.gov.my/web/guest/foreign-policy.

Ko, A, Not for Political Domination: China's Foreign Economic Policy towards Vietnam, Singapore and Malaysia in the Ppen Era. Disertasi Ph.D. University of Glasgow, 2010.

Koehane, R. After Hegemony: Cooperation and Discord in the World Political Economy, Princeton University Press, 2005.

Kuik, C.C, “Analyzing Malaysia's changing alignment choices, 1971-89," Jebat Vol. 37, 2010, hlmn. 41-74.

Kuik C. C.dan G. Rozman, "Introduction to Part 1: Light or Heavy Hedging: Positioning between China and the United States," dalam Gilbert Rozman, Joint U.S.-Korea Academic Studies 2015, Vol. 26, Korea Economic Institute of America, Washington DC, 2015, hlmn. $1-9$.

Kuik, C. C, "Making Sense of Malaysia's China Policy: Asymmetry, Proximity, and Elite's Domestic Authority," Chinese Journal of International Politics, Vol. 6, 2013, hlmn. 429-467. Lee Lai To, "Deng Xiaoping's ASEAN Tour: A Perspective on Sino-Southeast Asian Relations," Contemporary Southeast Asia, 3 (1), 1981, hlmn. 58-75.

Mahathir. M. 1999. A new deal for Asia. Subang Jaya: Pelanduk Publication.

Mauzy, D, Barisan Nasional: Coalition Government in Malaysia, Marican \& Sons (Malaysia), 1983.

Mitsuomi, I, “The Path To Malaysia's Neutral Foreign Policy In The Tunku Era”, Sarjana, 30 (2), 1995, hlmn 71-79.

Mohd Ikbal bin Huda, “Japan's Responses to China's Economic Incentives and Initiatives towards ASEAN," International Journal of East Asian Studies, 1 (1), 2017, hlmn. 1-20.

Ramli, D, Persepsi dan hubungan Malaysia-China 1974-2013, Universiti Malaysia Sabah, 2015.

Rose, G, "Neoclassical Realism and Theories of Foreign Policy," World Politics 5(1), 1998, hlm. 144-172

Saravanamuttu, J, Malaysia's Foreign Policy, the First Fifty Years: Alignment, neutralism, Islamism, Institute of Southeast Asian Studies, Singapore, 2010. 
Shee, P, K, “The Political Economy of Mahathir's China Policy: Economic Cooperation, Political and Strategic Ambivalence," Ritsumeikan Annual Review of International Studies, Vol. 3, 2004, hlmn. 59-79.

Suryadinata, L, Southeast Asia's Chinese Businesses in an Era of Globalization, ISEASYusof Ishak Institute, 2006.

Taliaferro, J.W. Lobell, S.E. and Ripsman, N.M, Neoclassical Realism, the State and Foreign Policy, Cambridge University Press, 2009.

Tan, A, Security Strategies in the Asia-Pacific: The United States' "Second Front" in Southeast Asia, Palgrave Macmillan, 2011. 